\title{
THE USE OF IRON OXIDE MAGNETIC NANOSPHERES AND NANOCUBES FOR TARGETED DOXORUBICIN DELIVERY INTO 4T1 MOUSE BREAST CARCINOMA CELLS
}

 \\ 'Laboratory of Biomedical Nanomaterials, National University of Science and Technology "MISiS", Moscow \\ ${ }^{2}$ Laboratory of Tissue-Specific Ligands, Faculty of Chemistry, Lomonosov Moscow State University, Moscow \\ ${ }^{3}$ Department of Physical Materials Science, National University of Science and Technology "MISiS", Moscow
}

\begin{abstract}
Magnetic nanoparticles (MNP) are attracting increasing attention as promising materials for the treatment and diagnosis of cancer. The aim of this work was to explore the effect of the magnetic core shape of iron oxide nanoparticles (NP) on the efficiency of doxorubicin delivery into 4T1 cells. Nanospheres (NS) and nanocubes (NC) were synthesized by thermal decomposition of iron (III) oleate. This method of synthesis enables control over the NP shape and size. The NP were hydrophilized using Pluronic F-127. The obtained particles were doped with doxorubicin in a sodium phosphate buffer. The weight fractions of doxorubicin in

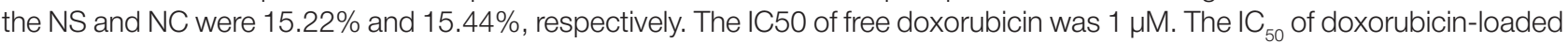
NS and NC were $6.4 \mu \mathrm{M}$ and $5.5 \mu \mathrm{M}$, respectively. Unloaded NP did not exhibit any toxicity towards the cells at a studied range of concentrations between $1.77 \mathrm{mg} / \mathrm{l}$ and $227.2 \mathrm{mg} / \mathrm{l}$. Free doxorubicin demonstrated more vigorous accumulation dynamics in $4 \mathrm{~T} 1$ cells with a tendency to localize in the cell nucleus, whereas doxorubicin loaded onto iron oxide NP was mainly accumulated in the vesicles surrounding the nucleus and was able to enter it only after being incubated with the cells for $2 \mathrm{~h}$. We conclude that doxorubicin loaded onto cubic-shaped NP is delivered into the cell nucleus a little bit more efficiently at early incubation stages in comparison with nanospheres, but the difference is insignificant.
\end{abstract}

Keywords: iron oxide nanoparticles, nanoparticle shape, cytotoxicity, drug delivery, doxorubicin

Funding: this work was supported by the Project 14.578.21.0201 (ID RFMEFI57816X0201).

$\triangle$ Correspondence should be addressed: Timur R. Nizamov

Leninsky prospect 4, Moscow, 119049; nizamov.timur@gmail.com

Received: 28.08.2018 Accepted: 20.09.2018

DOI: $10.24075 /$ brsmu.2018.085

\section{ИСПОЛЬЗОВАНИЕ МАГНИТНЫХ НАНОЧАСТИЦ ОКСИДА ЖЕЛЕЗА СФЕРИЧЕСКОЙ И КУБИЧЕСКОЙ ФОРМ ДЛЯ ДОСТАВКИ ДОКСОРУБИЦИНА В КЛЕТКИ ЛИНИИ КАРЦИНОМЫ МОЛОЧНОЙ ЖЕЛЕЗЫ МЫШИ 4Т1}

\author{
Т. Р. Низамов ${ }^{1 凶}$, А. С. Гаранина ${ }^{1,2}$, В. И. Уварова ${ }^{1,2}$, В. А. Науменко , И. В. Щетинин ${ }^{3}$, А. Г. Савченко ${ }^{1}$ \\ ' Лаборатория биомедицинских наноматериалов, Национальный исследовательский технологический университет «МИСиС», Москва \\ 2 Лаборатория тканеспецифических лигандов, Московский государственный университет имени М. В. Ломоносова, Москва \\ ${ }^{3}$ Кафедра физического материаловедения, Национальный исследовательский технологический университет «МИСиС», Москва
}

\begin{abstract}
Магнитные наночастицы (МНЧ) все больше привлекают внимание в качестве перспективного материала для разработки эффективных систем противоопухолевой терапии и диагностики. Целью работы было исследование влияния формы магнитного ядра наночастиц (НЧ) оксида железа на эффективность доставки доксорубицина в клетки линии 4 Т1. Наночастицы сферической (СНЧ) и кубической (КНЧ) форм синтезировали методом термического разложения олеата железа (III), что позволило эффективно контролировать их форму и размер. Затем НЧ гидрофилизировали посредством использования Pluronic F-127. В полученные средства доставки загружали доксорубицин в среде натрийфосфатного буфера. Загрузка составила 15,22\% для $\mathrm{CHЧ} \mathrm{и} \mathrm{15,44 \%} \mathrm{для} \mathrm{KHЧ}_{\text {. IC }}$ для незагруженного доксорубицина оказалась равной 1 мкМ, в то время как для СНЧ и КНЧ с препаратом - 6,4 мкМ и 5,5 мкМ соответственно. В протестированном диапазоне концентраций от 1,77 мг/л до 227,2 мг/л цитотоксичность у НЧ без препарата не выявлена. Согласно данным динамики накопления доксорубицина, в клетках 4T1 активнее всего идет накопление свободного препарата - он локализуется в клеточном ядре. В то же время доксорубицин, загруженный в НЧ, накапливается менее интенсивно и первоначально локализуется в везикулах вокруг ядра, обнаруживаясь в самом ядре лишь после 2 ч совместной инкубации. Противоопухолевый препарат, загруженный в КНЧ, несколько более активно доставляется на ранних сроках инкубации с клетками по сравнению со СНЧ, однако данная разница не существенна.
\end{abstract}

Ключевые слова: наночастицы оксида железа, форма наночастиц, цитотоксичность, адресная доставка, доксорубицин Финансирование: работа выполнена при поддержке Министерства образования и науки РФ, соглашение № 14.578.21.0201 (уникальный идентисикатор RFMEFI57816X0201).

$\varangle$ Для корреспонденции: Тимур Радикович Низамов

Ленинский пр-т, Д. 4, г. Москва, 119049; nizamov.timur@gmail.com

Статья получена: 28.08.2018 Статья принята к печати: 20.09.2018

DOI: $10.24075 /$ rrgmu. 2018.085 
Magnetic nanoparticles (MNP) including those derived from iron oxide are increasingly seen as holding promise for the design of efficient diagnostic platforms and therapeutic anticancer agents. State-of-the-art technologies provide tools for the synthesis of MNP with programmed properties and chemical modification of their surface for targeted drug delivery and MR imaging [1-5]. Because MNP have remarkable contrastenhancing properties, MNP-based drug delivery platforms can be employed to study the distribution of therapeutic agents in the target in real time and to assess the efficacy of treatment [6]. Other carriers, such as polymer NP, liposomes, micelles, etc., do not meet the requirements for contrast enhancement and, therefore, cannot be used to monitor drug distribution in vivo. That said, MNP have a number of drawbacks: they are toxic, tend to aggregate, and typically lack the ability to form stable covalent bonds with surface modifiers. These drawbacks can be overcome, though, by coating the NP surface with biocompatible polymers, thereby reducing NP toxicity and minimizing the risk of their aggregation. This approach is instrumental in achieving good contrast-enhancing properties, improved resistance to aggregation, and low toxicity; it also prepares the surface for further functionalization with ligands, therapeutic agents, vectors, etc. One approach to the design of MNP-based targeted drug delivery platforms stands out as innovative and promising. It consists of two steps. First, iron oxide nanoparticles are fabricated from iron (III) oleate by thermal decomposition in the presence of a stabilizing agent (oleic acid). Then, the obtained NP are transferred to an aqueous phase using Pluronic F-127, the poly(ethylene glycol)-block-poly(propylene glycol)-block-poly(ethylene glycol) copolymer with surfactant properties. The hydrophobic sites in the polymeric coating covering the NP facilitate delivery of hydrophobic drugs to the target [7-9].

There are a few factors driving the interactions between a drug delivery platform and biological molecules, including the chemical composition of an NP core and surface, as well as their geometry. The data describing how the shape of NP affects their cytotoxicity and cellular uptake is conflicting, suggesting that it is difficult to predict the behavior of nanoparticles in a living organism based on their geometry. For example, one of the studies demonstrated that carbon nanotubes induced more DNA damage in primary mouse embryo fibroblasts than less toxic carbon black nanocubes [10]. The authors of the study hypothesized that the effect was caused by the elongated shape of nanotubes with an aspect (length to width) ratio of 625 . Another research work reported that zinc oxide nanorods with an aspect ratio of 3 were less toxic against MG63 human osteosarcoma cells than nanospheres derived from the same material [11]. A group of researchers revealed that an increase in the aspect ratio of silica NP resulted in a slightly more pronounced cytotoxicity and better uptake by A375 human melanoma cells [12]. Another group investigated the impact of Ag NP geometry on the growth of S. cerevisiae and the intensity of cellular uptake [13]. Ag nanoplates proved to be less toxic than nanospheres, nanocubes and nanorods. The authors linked the described phenomenon to the chemically active $\{111\}$ facets dominating the surface of nanoplates that enhanced NP cytotoxicity against yeast. In a study carried out by different authors, Au nanospheres were more vigorously accumulated in MDCK II epithelial cells than Au nanorods and exhibited higher cytotoxicity [14]. At the same time, no data is available on the role of an MNP shape in targeted drug delivery and cytotoxicity.

Doxorubicin is a well-known and widely used chemotherapy drug with antiproliferative activity. It was introduced in clinical practice 40 years ago. However, poor selectivity and high toxicity against healthy cells impose certain limitations on its use. The most dangerous side effects of doxorubicin include cardiomyopathy and cardiac failure [15]. They dictate a need for innovative targeted drug delivery systems that can overcome the drawbacks of doxorubicin therapy. The solution is offered by Pluronic F-127-based carriers [9]. Doxorubicin is capable of binding to the hydrophobic sites of surfactants that stabilize the NP surface. The release of the drug is induced either by Brownian relaxation after applying an external magnetic field or by the acid environment of lysosomes once the particle is taken up by the cell [16].

The aim of the present study was to investigate the effect of spherical and cubic shapes of iron oxide NP modified with Pluronic F-127 and doped with doxorubicin on the cytotoxicity of the particles against 4TI mouse mammary carcinoma cells, the efficacy of their targeted delivery into the cells and distribution of the drug inside the cells.

\section{METHODS}

The following reagents were used: Pluronic F-127 (Sigma Aldrich; USA); deionized water; chemically pure toluene (Komponent-reaktiv, Russia); iron (III) chloride, 97\% (Sigma Aldrich; USA); oleic acid, $\geq 99 \%$ (Roth; Germany); sodium oleate, 95\% (Roth; Germany); chemically pure hydrochloric acid (SigmaTek; Russia); ferrozine, $\geq 97 \%$ (Sigma Aldrich; USA); ammonium acetate, $\geq 98 \%$ (Sigma Aldrich; USA); ascorbic acid, $\geq 99 \%$ (Sigma Aldrich; USA); doxorubicin hydrochloride, $\geq 98 \%$ (Glentham; UK); sodium phosphate buffer tablets, biotechnology grade (Amresco; USA); chemically pure isopropanol (SigmaTek; Russia); 1-octadecene, $\geq 95 \%$ (Sigma Aldrich; USA); ethanol, $\geq 95 \%$ (Sigma Aldrich; USA); chemically pure hexane (SigmaTek; Russia); MTS (Promega; USA); dimethyl sulfoxide, $\geq 99 \%$ (Sigma Aldrich; USA); iron standard for ICP (Sigma Aldrich; USA).

\section{Synthesis of carriers and doxorubicin loading}

\section{Synthesis of nanospheres and nanocubes}

Nanospheres were synthesized by thermal decomposition of iron oleate following the original yet slightly modified technique described in $[17,18]$. Briefly, sodium oleate $(100 \mathrm{mmol})$ and anhydrous iron (III) chloride $(33 \mathrm{mmol})$ were dissolved in a mixture of ethanol $(66.7 \mathrm{ml})$, water $(50 \mathrm{ml})$ and hexane $(116 \mathrm{ml})$ under vigorous stirring. The resulting solution was heated to $70{ }^{\circ} \mathrm{C}$ and stirred at that temperature for 4 hours. Then, the organic phase was separated and the solvent was gradually evaporated using a rotovap until a brown waxy complex of iron (III) oleate was formed. After that, $2.2 \mathrm{mmol}$ of the obtained iron oleate and $12 \mathrm{mmol}$ of oleic acid were dissolved in $10 \mathrm{ml}$ of 1 -octadecene. The mixture was heated to $320{ }^{\circ} \mathrm{C}$ at a rate of $3.3^{\circ} \mathrm{C} / \mathrm{min}$ under vigorous stirring under argon flow and then incubated at $320^{\circ} \mathrm{C}$ for $60 \mathrm{~min}$. Following incubation, the mixture was cooled down to room temperature and diluted fivefold with isopropanol. Nanoparticles were collected using a neodymium magnet and washed in isopropanol 3 times. The precipitate was re-dispersed by sonication in toluene.

Nanocubes were synthesized by thermal decomposition of iron (III) oleate [19]. The original protocol was slightly modified. Briefly, $33 \mathrm{ml}$ of a solution containing the iron oleate complex (4 mmol), sodium oleate (1.3 mmol) and oleic acid (1.3. mmol) were poured into a three-necked flask equipped with a $100 \mathrm{ml}$ 
reflux condenser. The mixture was heated to $140^{\circ} \mathrm{C}$ and kept at that temperature for $60 \mathrm{~min}$ to remove residual water. Then, the mixture was brought to the boiling point at a rate of $4{ }^{\circ} \mathrm{C} / \mathrm{min}$ and was allowed to boil for $30 \mathrm{~min}$. All manipulations were performed under argon flow. The obtained solution was cooled down to room temperature. The obtained NP were isolated by adding $320 \mathrm{ml}$ of isopropanol solution followed by magnetic decantation. The final product was washed in isopropanol 3 times and re-dispersed in toluene.

\section{Ferrozine assay}

Ammonium acetate (385.4 mg), ferrozine (3.2 mg) and ascorbic acid (352.2 mg) were weighed and dissolved in $1 \mathrm{ml}$ of deionized water. The obtained solution was later used to spectrophotometrically measure iron concentrations.

\section{Phase transfer of nanoparticles assisted by Pluronic F-127}

Phase transfer of the synthesized NP to an aqueous phase was aided by the nonionic surfactant Pluronic F-127 using the technique described in $[20,21]$, which we slightly modified. Briefly, $15 \mathrm{ml}$ of the NP solution in toluene with an iron oxide concentration of $1 \mathrm{mg} / \mathrm{ml}$ were combined with the same volume of Pluronic F-127 solution in water (Pluronic concentration $\mathrm{C}=25 \mathrm{mg} / \mathrm{ml})$. The mixture was incubated overnight under vigorous stirring. The emulsion was separated by centrifugation at $1,000 \mathrm{~g}$ and the aqueous phase was collected. Then, the aqueous phase was again centrifuged at $12,000 \mathrm{~g}$ to stimulate precipitation of magnetite NP. Finally, the precipitate was redispersed under sonication in deionized water. The solution was diluted to achieve an iron oxide concentration of $0.32 \mathrm{mg} / \mathrm{ml}$.

Loading of doxorubicin onto iron oxide nanoparticles coated with Pluronic F-127

The aqueous solution of $5 \mathrm{mg} / \mathrm{ml}$ doxorubicin $(0.2 \mathrm{ml})$ and the phosphate buffered saline $(0.2 \mathrm{ml})$ concentrated fivefold relative to the isotonic solution $(\mathrm{pH}=7.4)$ were added to $10 \mathrm{ml}$ of the obtained aqueous solution of NP and stirred on the magnetic stirrer at room temperature for $24 \mathrm{~h}$. The total doxorubicin concentration in the NP solution $\mathrm{C}_{\text {total }}$ (dox) was $96.0 \mathrm{mg} / \mathrm{ml}$. Then the solution was centrifuged to precipitate all NP. The
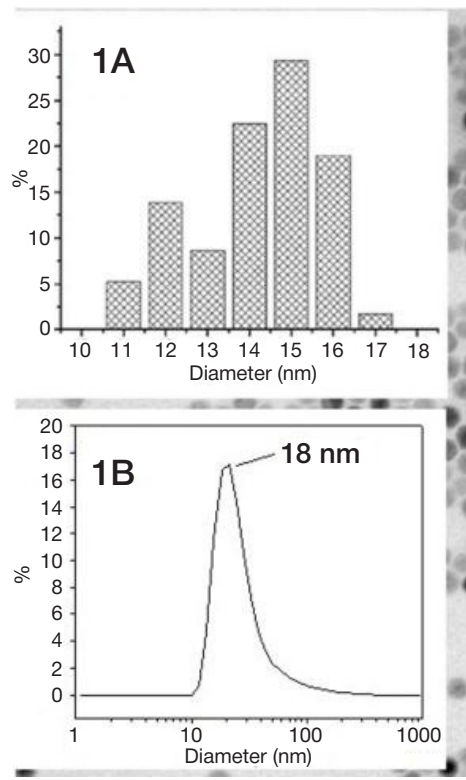

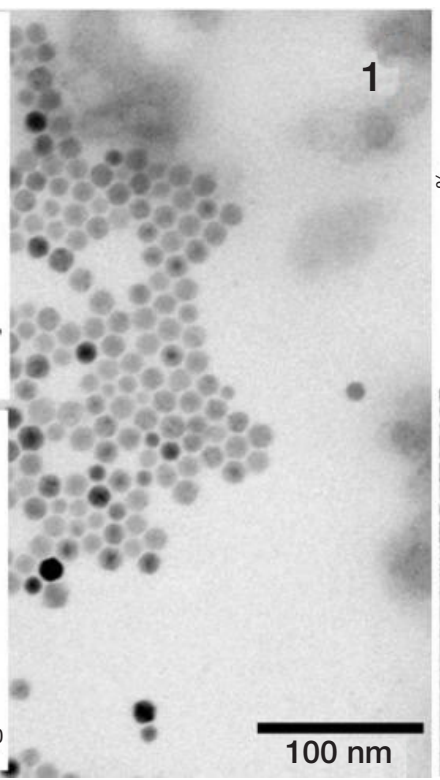

collected NP were re-dispersed in the sodium phosphate buffer under vigorous stirring using a shaker.

\section{Characteristics of synthesized magnetic nanoparticles}

\section{Transmission electron microscopy (TEM)}

The morphology and size of the nanoparticles were examined under the $200 \mathrm{kV}$ FE transmission electron microscope JEOL JEM-2100F (JEOL; Japan) operated at a beam current of $0.8 \mathrm{~A}$. The samples for TEM were prepared by applying $1-2 \mu \mathrm{l}$ of the NP solution onto a formvar-coated copper mesh $(d=3.05 \mathrm{~mm})$ and allowing them to air-dry.

\section{Dynamic light scattering}

The hydrodynamic size of the nanoparticles and their zetapotential were measured in the volumes ranging from 1 to $2 \mathrm{ml}$ using the Zetasizer Nano ZS analyzer (Malvern; Germany).

\section{Vibrating-sample magnetometry}

Magnetic properties of the particles were evaluated using the Quantum Design Physical Property Measurement System (PPMS; Germany) equipped with a vibrating sample magnetometer (oscillation amplitude of $2 \mathrm{~mm}$, frequency of $40 \mathrm{~Hz}$, sensitivity of $10^{-6} \mathrm{emu}$ ).

\section{$X$-ray diffraction analysis $(X R D)$}

The crystalline structure of the synthesized MNP was characterized using the DRON-4 diffractometer (Burevestnik; Russia) with the following parameters: cobalt $X$-ray source with $\lambda=0.179 \mathrm{~nm}$, voltage of $40 \mathrm{kV}$, current of $30 \mathrm{~mA}$. The samples were scanned through a range of diffraction angles $2 \theta$ from $20^{\circ}$ to $120^{\circ}$ by increments of $0.1^{\circ}$. Exposure time was 3 seconds per frame.

\section{Spectrophotometry}

1. Doxorubicin concentration measurement and loading efficiency. $600 \mathrm{m \mu}$ of doxorubicin solutions were introduced into two wells of a 96 -well plate (300 mu per well). Absorption

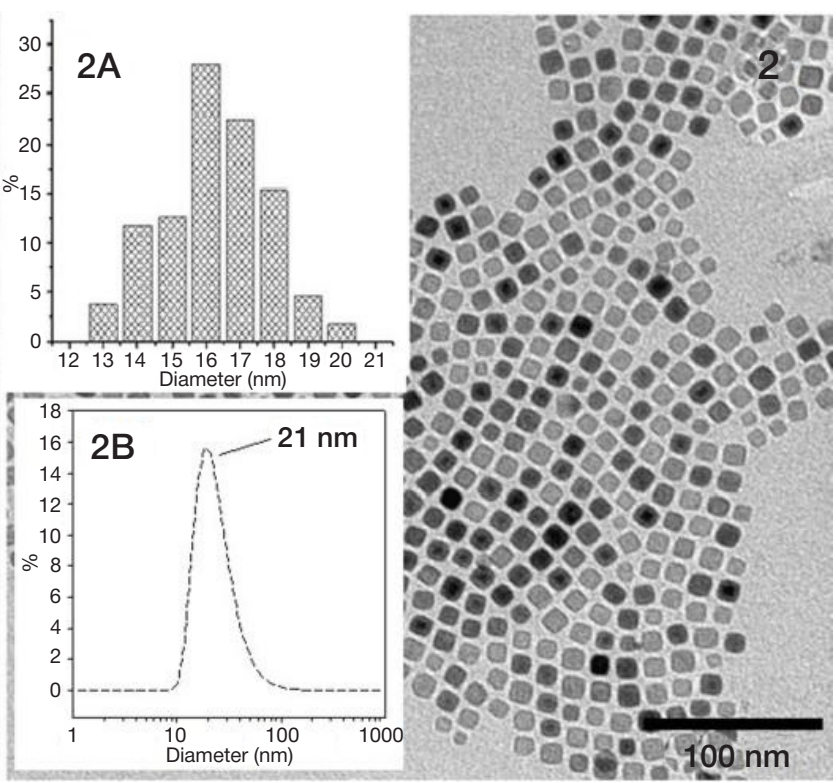

Fig. 1. Microimages of iron oxide NS (1) and NC (2), histograms of size distribution and average hydrodynamic size of the particles 
was measured at $\lambda=495 \mathrm{~nm}$ by the Multiskan $\mathrm{GO}$ spectrophotometer (Thermo Scientific; USA). The concentration of doxorubicin was calculated based on a 6-point calibration curve $(1,0 ; 2,5 ; 5,0 ; 10,0 ; 25,0 ;$ and $50 \mu \mathrm{kg} / \mathrm{ml})$. The amount of loaded doxorubicin $\left(\mathrm{C}_{\text {load }}(\mathrm{dox})\right)$ was calculated by measuring the residual concentration of the drug in the supernatant $\left(\mathrm{C}_{\text {res }}(\right.$ dox $\left.)\right)$ yielded by centrifugation, which was subtracted from the initial concentration of the drug $\mathrm{C}_{\text {total }}(\mathrm{dox})$ in the solution. Encapsulation efficiency was calculated by the formula: $\omega=100 \% \cdot C_{\text {load }}($ dox $) /\left(C_{\text {load }}(\right.$ dox $\left.)+C(N P)\right)$, where $C_{\text {load }}($ dox $)$ is a concentration of the loaded doxorubicin expressed as $\mathrm{mg} / \mathrm{l}$ and $\mathrm{C}(\mathrm{NP})$ is a concentration of NP $=308 \mathrm{mg} / \mathrm{l}$.

2. Iron concentration. A series of iron ICP standard solutions were prepared with concentrations of $0.1,0.25,0.5,0.75,1$, 1.5 , and $2 \mathrm{mg} / \mathrm{ml}$. Briefly, $100 \mathrm{m \mu}$ of a sample with known iron concentrations were incubated with $400 \mathrm{m \mu}$ of concentrated hydrochloric acid for $2 \mathrm{~h}$. Then, the solution was diluted 100fold with deionized water, and $400 \mathrm{m \mu}$ of the obtained mixture were combined with $200 \mathrm{m \mu}$ of deionized water and $40 \mathrm{m \mu}$ of the ferrozine assay prepared in advance. Five minutes later, the resulting product was transferred to two wells of a 96-well plate (300 $\mathrm{m} \mu$ per well), and its absorption was measured at $\lambda=560 \mathrm{~nm}$ by Multiskan GO in the photometry mode. Iron concentration was inferred from the absorption data.

\section{Cell culture}

4T1 mouse mammary carcinoma cells (ATCC ${ }^{\circledR}$ CRL-2539 ${ }^{\mathrm{TM}}$, USA) were cultured in the RPMI-1640 medium (Gibco) supplemented with $2 \mathrm{mM} \mathrm{L-glutamine} \mathrm{(Gibco)} \mathrm{and} \mathrm{10 \%} \mathrm{fetal}$ bovine serum (Gibco) at $37^{\circ} \mathrm{C}$ and $5 \% \mathrm{CO}_{2}$.

\section{MTS cytotoxicity assay}

The cells were seeded in a 96-well plate $(12,000-15,000$ cells per well) and left there for $24 \mathrm{~h}$ before introducing the particles. Free doxorubicin, doxorubicin-loaded nanoparticles and nanoparticles without the drug were dissolved in the sodium phosphate buffer and added to the cells at various concentrations. Cell cultures supplemented with the buffer were used as a negative control. Cell cultures supplemented with dimethyl sulfoxide (20 $\mathrm{m \mu}$ of the reagent per $100 \mathrm{m \mu}$ of the medium) were used as a positive control. The cells were incubated with the NP and the controls in the incubator at $37^{\circ} \mathrm{C}$ and $5 \% \mathrm{CO}_{2}$ for $48 \mathrm{~h}$. Upon incubation, the number of viable cells in each well was determined by the MTS assay. Briefly, the culture medium was replaced with an MTS solution in the fresh medium (20 $\mathrm{m \mu}$ of MTS per $100 \mathrm{m \mu}$ medium) and incubated for $4 \mathrm{~h}$ in the dark at $37{ }^{\circ} \mathrm{C}$ and $5 \% \mathrm{CO}_{2}$. Then, the plates were mounted on a permanent magnet and left to sit there for 5 min to separate the nanoparticles. After that, samples were carefully collected from each well and transferred to another plate to avoid contamination with NP. The optical density of the samples was measured spectrophotometrically at $\lambda=490 \mathrm{~nm}$. Histograms of cell survival were constructed and standard deviation was calculated in Microsoft Office Excel 2007.

\section{Accumulation dynamics of free and NP-loaded doxorubicin}

The cells were seeded onto Petri dishes at 120,000-150,000 cells per dish. Free doxorubicin and doxorubicin loaded onto $\mathrm{NC}$ and NS (drug concentrations of $50 \mu \mathrm{kg} / \mathrm{ml}$ ) were introduced into culture samples 24 hours later. The cells incubated with the drug- or NP-free medium were used as a control. The cultures were incubated with the studied samples for 15,30 , $45 \mathrm{~min}$ and $1 \mathrm{~h}, 2 \mathrm{~h}, 4 \mathrm{~h}, 6 \mathrm{~h}, 24 \mathrm{~h}$. Upon incubation, the cells were fixed in $3.7 \%$ formalin solution in the sodium phosphate buffer (pH 7.2-7.4; Gibco) for 15 min. The obtained samples were examined under the fluorescence microscope EVOS equipped with the LplanFL PH2 $\times 60$ lens (Life technologies; USA). The images were processed and fluorescence intensity was measured in ImageJ 1.52a (Wayne Rasband (NIH); USA). A single factor ANOVA test was applied to carry out statistical analysis. Differences were considered significant at $p<0.05$.

\section{RESULTS}

Iron oxide NP synthesized by thermal decomposition were studied using TEM (Fig. 1). The histogram of size distribution shows that the technique for the synthesis of nanospheres yielded magnetite particles with an average size of $15 \mathrm{~nm}$ (Fig. 1-1A). As we expected, the fabricated NP had a spherical shape. The average hydrodynamic size of the nanospheres in toluene was about $18 \mathrm{~nm}$ (Fig. 1-1B).

The samples synthesized according to the protocol for the fabrication of nanocubes were also characterized using TEM (Fig. 1-2). As we expected, the resulting NP with an

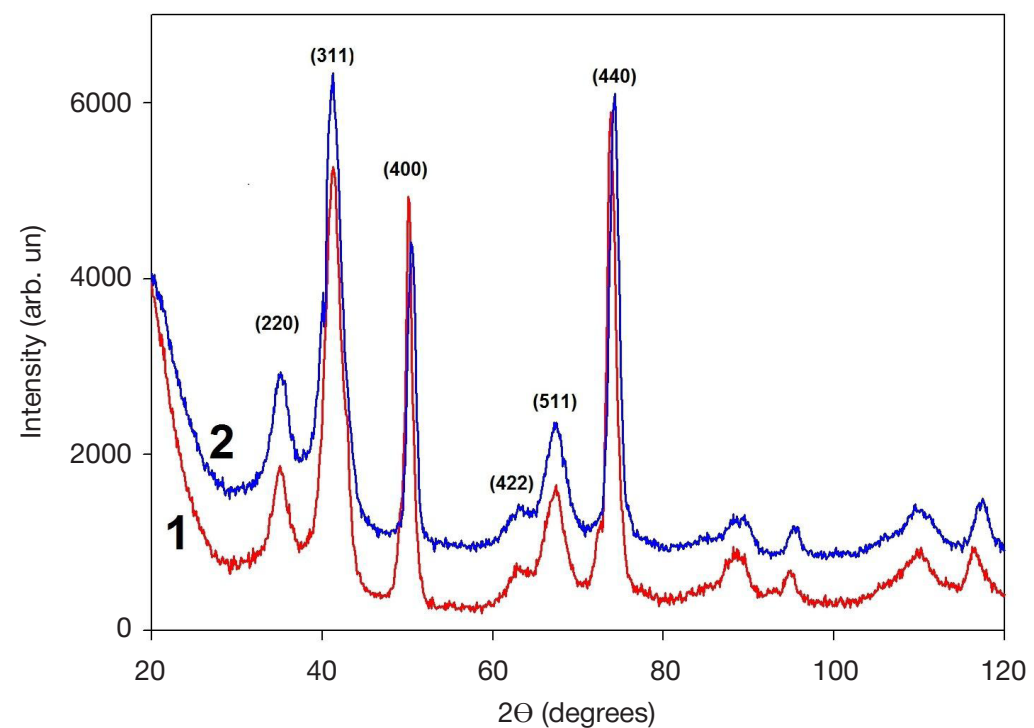

Fig. 2. Data yielded by the XRD analysis for NS (1) and NC (2) 
average size of $16 \mathrm{~nm}$ had a cubic shape (Fig. 1-2A). The average hydrodynamic size of nanocubes was about $21 \mathrm{~nm}$ (Fig. 1-2B)

The $\mathrm{X}$-ray diffraction analysis of the nanospheres revealed that the position of the diffraction peaks and their intensity were indicative of the inverse spinel structure typical of magnetite (Fig. 2-1). Nanocubes had a similar structure (Fig. 2-2). More information is available in the Table below.

Measurements of magnetic properties revealed that the magnetic saturation Ms of the nanospheres was $50.5 \mathrm{emu} / \mathrm{g}$, and coercivity Hc was 20.5 Oe (Fig. 3-1). Magnetic properties of the nanocubes were comparable: magnetic saturation was 60.5 emu/g and coercivity was 20.0 Oe (Fig. 3-2).

The average hydrodynamic size of NP after the phase transfer from toluene to water and stabilization with Pluronic F-127 increased to $43 \mathrm{~nm}$ for NS (Fig. 4-1) and to $50 \mathrm{~nm}$ for $\mathrm{NC}$ (Fig. 4-2), whereas their zeta-potentials were $-10 \mathrm{mV}$ and $-15.1 \mathrm{mV}$, respectively. After the particles were loaded with doxorubicin, the average size of NS reached $68 \mathrm{~nm}$ (Fig. 4-3), whereas their zeta-potential became positive $(+21.1 \mathrm{mV})$. A similar tendency was observed for NC: their hydrodynamic size increased to $78 \mathrm{~nm}$ (Fig. 4-4), and their zeta-potential was now $+22.0 \mathrm{mV}$. The amount of doxorubicin loaded onto the NS was calculated as follows: the concentration of the drug in the supernatant $\mathrm{C}_{\text {res }}($ dox $)$ was $40.7 \mathrm{mg} /$; therefore, $\mathrm{C}_{\text {load }}($ dox $)=$ $\mathrm{C}_{\text {total }}(\mathrm{dox})-\mathrm{C}_{\text {res }}($ dox $)=96.0-40.7=55.3 \mathrm{mg} / \mathrm{ml}$. The mass percentage of the drug in the NS $\omega(\mathrm{NS})=100 \% \cdot \mathrm{C}_{\text {load }}($ dox $) /$ $\left(\mathrm{C}_{\text {load }}(\mathrm{dox})+\mathrm{C}(\mathrm{NP})\right)=100 \% \cdot 55.3 /(55.3+308)=15.22 \%$. The amount of doxorubicin loaded onto the NC was calculated as follows: $\mathrm{C}_{\text {load }}($ dox $)=39.2 \mathrm{mg} / \mathrm{l}$; then $\mathrm{C}_{\text {load }}($ dox $)=\mathrm{C}_{\text {total }}($ dox $)-$ $\mathrm{C}_{\text {res }}(\mathrm{dox})=96.0-39.2=56.2 \mathrm{mg} / \mathrm{l}$. In the case of the NC, $\omega(\mathrm{NC})=100 \% \cdot \mathrm{C}_{\text {load }}(\mathrm{dox}) /\left(\mathrm{C}_{\text {load }}(\mathrm{dox})+\mathrm{C}(\mathrm{NP})\right)=100 \% \cdot 56.2 /$ $(56.2+308)=15.44 \%$.

It was established that all studied concentrations of $\mathrm{NC}$ and NS were not toxic against 4T1 cells (Fig. 5A). However, after the cells were incubated with the same concentrations of doxorubicin-loaded NS and NC, the number of viable cells in the cultures decreased. $I_{50}$ (the half maximal inhibitory concentration) of the NC doped with doxorubicin (NC-Dox) was $21 \mathrm{mg} / \mathrm{l}$ iron oxide and $5.5 \mu \mathrm{M}$ doxorubicin. For the NS doped with doxorubicin (NS-Dox), $\mathrm{IC}_{50}$ was $25 \mathrm{mg} / \mathrm{l}$ and $6.4 \mu \mathrm{M}$ for iron oxide and the drug, respectively. $I C_{50}$ of free doxorubicin was about $1 \mu \mathrm{M}$ (Fig. 5B). It means that NC-Dox had a slightly more pronounced tumoricidal effect than NS-Dox. However, this difference was insignificant. Free doxorubicin was the most effective of all drug variations in killing the cells.

The analysis of the accumulation dynamics of free and NPbound doxorubicin in the cells demonstrated than after 15 min of incubation with the cells, a weak fluorescence signal was recorded coming from doxorubicin. After 30 min of incubation, the intensity of the signal emitted from free doxorubicin was comparable to that of doxorubicin delivered to the cells by NC. However, free doxorubicin tended to accumulate mostly in the nuclei, whereas doxorubicin loaded onto NC was visualized in the vesicles near the nucleus (Fig. 6A, D, L). The fluorescence signal emitted from NS-Dox was significantly less intense than

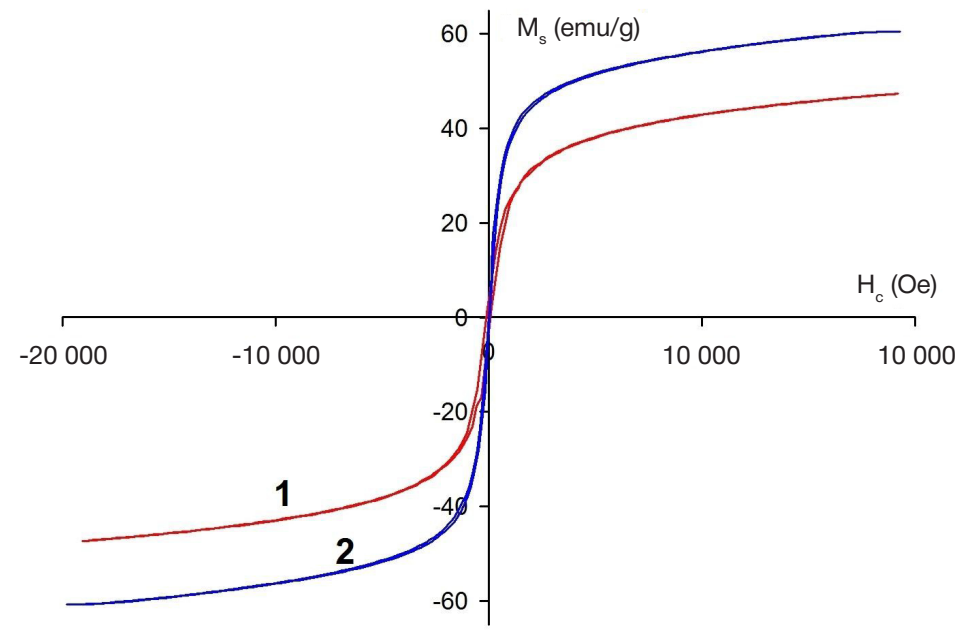

Fig. 3. Magnetization curves for NS (1) and NC (2)

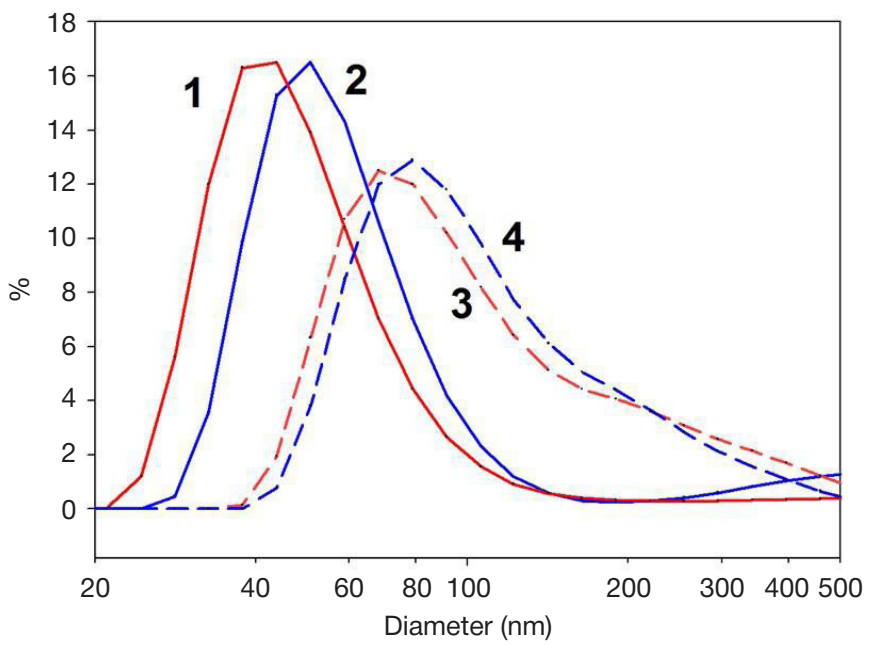

Fig. 4. The hydrodynamic size of NP after transfer to an aqueous phase: NS before (1) and after (3) doxorubicin loading; NC before (2) and after (4) doxorubicin loading. 
A

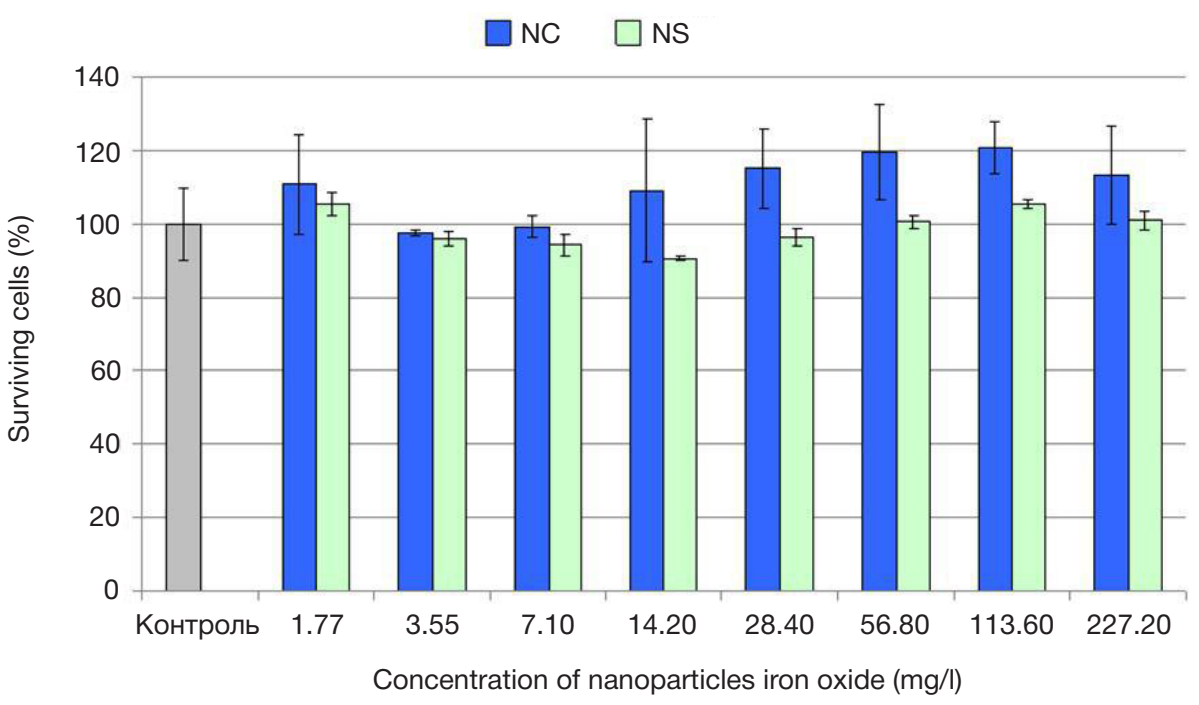

B

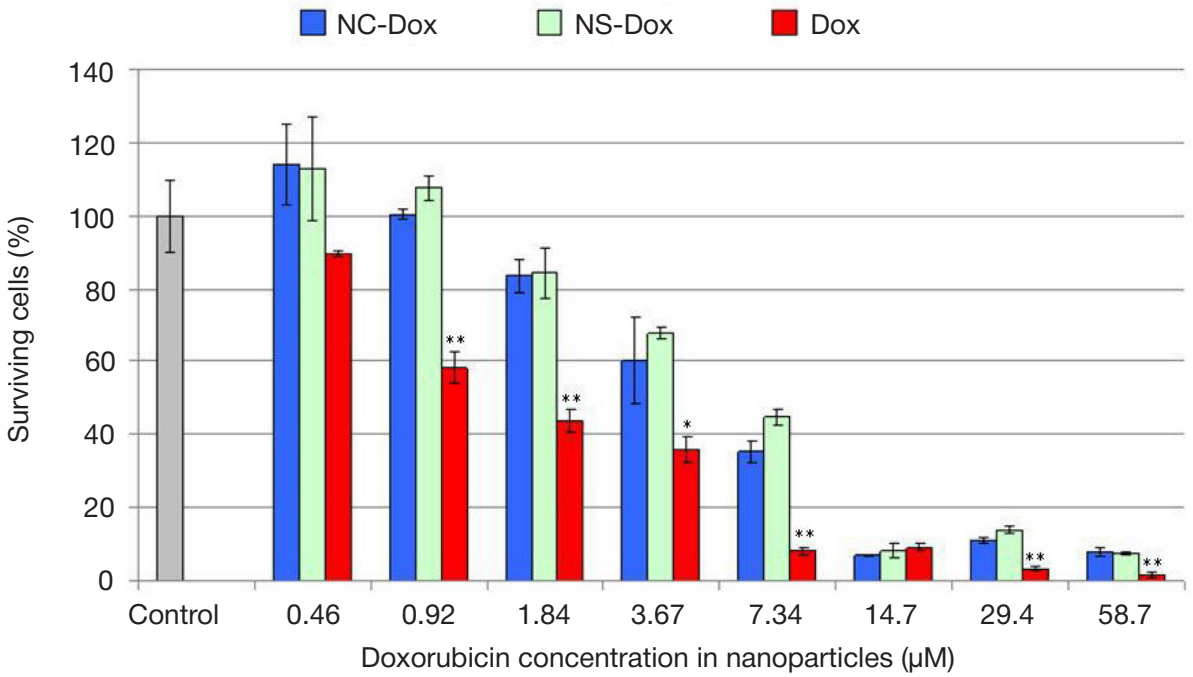

Fig. 5. Toxicity of NP against the 4T1 cell line. The histogram shows cell survival after $48 \mathrm{~h}$ incubation with NC and NS (A); after 48-h incubation with NC-Dox, NS-Dox and free doxorubicin (B). The MTS assay. Results are presented as mean values \pm SD. ${ }^{\star} p<0.05 ;{ }^{* \star} p<0.01$. Percentage of living cells incubated with the sodium phosphate buffer was taken as 100\%

that of NC-Dox and free doxorubicin (Fig. 6G). This tendency was also observed after 45 min-long incubation of the cells with the free and NP-loaded drug. In later periods, the fluorescence intensity of the drug did not differ significantly between the types of its carriers. However, accumulation of free doxorubicin was more pronounced than that of the loaded drug. It should be noted that the drug was visualized mainly in cell nuclei only after the cells were incubated with NC-Dox and NS-Dox for $2 \mathrm{~h}$. Thus, the efficiency of drug delivery is higher for free doxorubicin than for the drug carried by NP. It was also established that NC penetrate cells more readily than NS, but this difference levels out over time.

\section{DISCUSSION}

Thermal decomposition of iron (III) oleate is a method for fabricating stable sols of monodisperse iron oxide NP with programmed sizes and shapes: spherical [17, 18], cubic [19], and some other. [22]. The initial iron (III) oleate complex decomposes at high temperatures and can be partially reduced to $\mathrm{Fe}$ (II) by the components of the reaction mixture producing magnetite $\left(\mathrm{Fe}_{3} \mathrm{O}_{4}\right)$ or maghemite $\left(\gamma-\mathrm{Fe}_{2} \mathrm{O}_{3}\right)$ nanoparticles. Both oxides have ferrimagnetic properties. The final size and shape of NP are determined by the presence of stabilizing agents in the reaction mixture, such as oleic acid and sodium oleate. They are capable to selectively adsorb to the $\{111\}$ facets of growing NP and shape their geometry. By adsorbing to the surface of NP, stabilizing agents confer hydrophobicity critical for the design of platforms for the targeted delivery of hydrophobic drugs, including doxorubicin.

During the experiment, we fabricated nanocubes and nanospheres and stabilized them with Pluronic F-127 (Fig. 1). The analysis of their structure (Fig. 2) and magnetic properties (Fig. 3) revealed that the synthesized particles were iron oxide compositions with the inverse spinel structure. Because the NP size identified by TEM did not coincide with the size of the coherent scattering region, we concluded that the samples were polycrystalline (Table). The coercivity of both samples was $>0$, meaning the latter were ferrimagnetic.

The samples were stable both in hydrophobic media (Fig. 1-1B, Fig. 1-2B) and in an aqueous phase containing Pluronic F-127 (Fig. 4-1, Fig. 4-2). This polymer has a hydrophobic site of polypropylene glycol allowing it to adsorb onto the NP surface and two hydrophilic terminal regions of polyethylene glycol pointing towards the outside. Transferred to an aqueous phase, NP acquire hydrophobic sites, which can bind hydrophobic drugs, and a hydrophilic shell, which considerably improves the solubility of NP in aqueous media. 
$30 \mathrm{~min}$


$2 \mathrm{~h}$

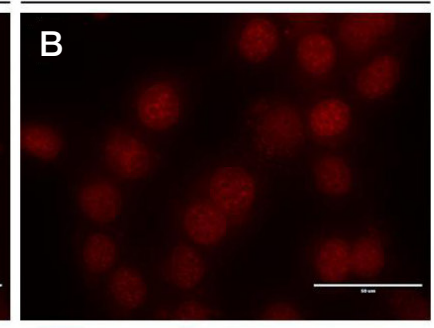

E
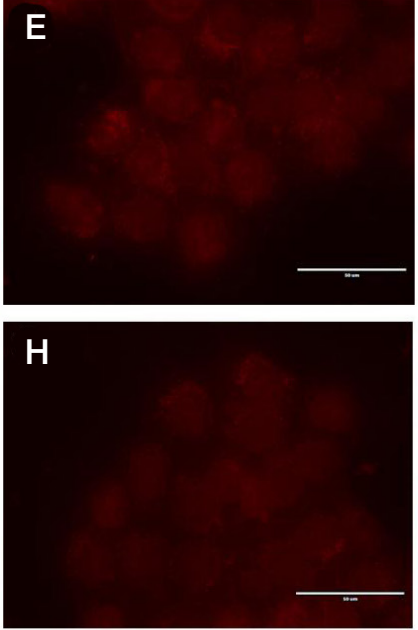

K $\square$ Dox $\quad$ NC-Dox $\square$ NS-Dox

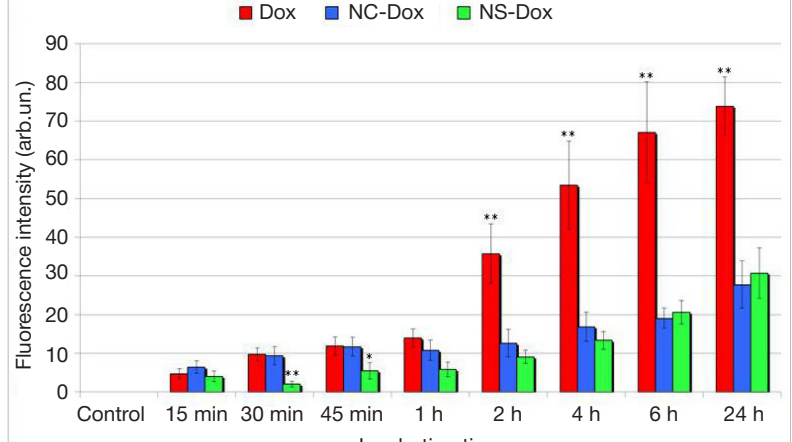

Incubation time

$6 \mathrm{~h}$
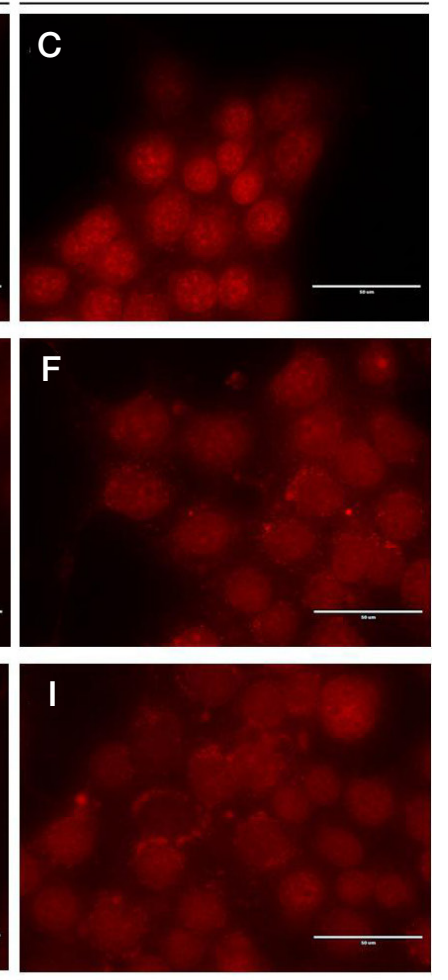

Fig. 6. Accumulation dynamics of free and entrapped doxorubicin in 4T1 cells. Fluorescence microscopy (A-J); a histogram showing the relationship between the intensity of doxorubicin fluorescence in the cells and the time of cell incubation with Dox, NC-Dox and NS-Dox (K). Results are presented as mean values \pm SD. ${ }^{\star} p<0.05 ;{ }^{* *} p<0.01$

The increase in the hydrodynamic size of NP in the aqueous solution is also associated with the adsorption of a stabilizing agent.

Doxorubicin is poorly soluble in water; therefore, in clinical practice its hydrochloride derivative is used instead. The polymer shell of nanoparticles is loaded with the drug in a sodium phosphate buffer where doxorubicin hydrochloride molecules are deprotonated and crystals start to form from its poorly soluble base. If the medium contains NP with hydrophobic sites, deprotonated doxorubicin can adsorb onto them. This also leads to an increase in the hydrodynamic size of NP doped with the drug and surface recharge (Fig. 4-3, Fig. 4-4). The entrapped drug can be protonated in a more acidic environment of cellular lysosomes ( $\mathrm{pH} 4.5-5)$ and released from the polymer shell of the particles [16].

Recently a number of publications have demonstrated the advantages of nonspheric NP for hyperthermia therapy and MR imaging. There are reports that nanocubes [23, 24] and octopods [25] have higher SAR in comparison with nanospheres and therefore are suitable for magnetic hyperthermia. Besides, magnetic nanocubes have higher T2 relaxation values than their spherical counterparts [26]. Considering the above said, we decided to conduct the comparative analysis of the impact
Table. Results of the XRD analysis of NS and NC

\begin{tabular}{|c|c|c|c|c|}
\hline & Phase & DTEM, nm & $\begin{array}{c}\text { CSR, } \\
\mathrm{nm}\end{array}$ & Lattice constant, nm \\
\hline $\mathrm{NS}$ & $\mathrm{Fe}_{3} \mathrm{O}_{4}(100 \%)$ & $11-17$ & $6 \pm 1$ & $0.8373 \pm 0.0004$ \\
\hline $\mathrm{NC}$ & $\mathrm{Fe}_{3} \mathrm{O}_{4}(100 \%)$ & $13-20$ & $6 \pm 1$ & $0.8378 \pm 0.0004$ \\
\hline
\end{tabular}

of NS and NC on mouse mammary carcinoma cells and on the efficiency of drug delivery to the cells.

We established that at concentrations of up to $227 \mathrm{mg} / \mathrm{l}$ both shapes do not exhibit cytotoxicity. NC loaded with doxorubicin induced a slightly more significant cell death than NS. A possible explanation here is that NC penetrate the cell faster than NS. But this difference was insignificant in our experiment. Free doxorubicin has a significantly more powerful tumoricidal effect and more readily accumulates in cell nuclei, perhaps due to the fact that free doxorubicin enters the cell by diffusion, whereas the drug carried by NP is endocytosed, which takes longer. Importantly, the particles loaded with doxorubicin are first visualized in intracellular vesicles (probably, lysosomes) where it is later protonated. Only after that the drug can be released from its carrier and transported into the nucleus 
[27]. Summing up, doxorubicin carried to the cell by NP has a weaker tumoricidal effect but the platform can be modified by attaching specific ligands to the NP surface in order to achieve improved cytotoxicity [28].

\section{CONCLUSIONS}

Our study revealed that the efficiency of free doxorubicin delivery to $4 \mathrm{~T} 1$ mouse mammary carcinoma cells is higher than that of the drug loaded onto NS and NC. Free doxorubicin enters the cell by diffusion and accumulates in the cell nucleus. If the drug is carried to the cell by iron oxide nanoparticles, it is endocytosed and then accumulates in the vesicles. Then it is gradually released into the intracellular environment. Partial release results in lower $\mathrm{IC}_{50}$ of the loaded drug in comparison with free doxorubicin. Although NC were more efficient than NS in delivering the drug into the cells, this difference was insignificant.

\section{Литература}

1. Ling D, Hyeon T. Chemical design of biocompatible iron oxide nanoparticles for medical applications. Small. 2013; 9 (9-10): 1450-66. DOl:10.1002/smll.201202111.

2. Majewski P, Thierry B. Functionalized Magnetite Nanoparticles Synthesis, Properties, and Bio-Applications. Crit Rev Solid State Mater Sci. 2007; 32 (3-4): 203-15.DOI:10.1080/10408430701776680.

3. Xie J, Huang J, Li X, Sun S, Chen X. Iron oxide nanoparticle platform for biomedical applications. Curr Med Chem. 2009; 16 (10): 1278-94. DOI:10.2174/092986709787846604.

4. Oh JK, Park JM. Iron oxide-based superparamagnetic polymeric nanomaterials: Design, preparation, and biomedical application. Prog Polym Sci. 2011; 36 (1): 168-89. DOI:10.1016/j. progpolymsci.2010.08.005.

5. Laurent S, Forge D, Port M, Roch A, Robic C, Vander Elst L et al. Magnetic iron oxide nanoparticles: Synthesis, stabilization, vectorization, physicochemical characterizations and biological applications. Chem Rev. 2008; 108 (6): 2064-110. DOl:10.1021/ cr068445e.

6. Lin JJ, Chen JS, Huang SJ, Ko JH, Wang YM, Chen TL et al. Folic acid-Pluronic F127 magnetic nanoparticle clusters for combined targeting, diagnosis, and therapy applications. Biomaterials. 2009; 30 (28): 5114-24. DOI:10.1016/j.biomaterials.2009.06.004.

7. Andhariya N, Chudasama B, Mehta RV, Upadhyay RV. Biodegradable thermoresponsive polymeric magnetic nanoparticles: A new drug delivery platform for doxorubicin. J Nanoparticle Res. 2011; 13 (4): 1677-88. DOl:10.1007/s11051-010-9921-6.

8. Tavano L, Vivacqua M, Carito V, Muzzalupo R, Caroleo MC, Nicoletta F. Doxorubicin loaded magneto-niosomes for targeted drug delivery. Colloids Surfaces B Biointerfaces. 2013; (102): 803-7. DOI:10.1016/j.colsurfb.2012.09.019.

9. Jain TK, Foy SP, Erokwu B, Dimitrijevic S, Flask CA, Labhasetwar V. Magnetic resonance imaging of multifunctional pluronic stabilized iron-oxide nanoparticles in tumor-bearing mice. Biomaterials. 2009; 30 (35): 6748-56. DOI:10.1016/j.biomaterials.2009.08.042.

10. Yang $H$, Liu C, Yang D, Zhang $H, X i$ Z. Comparative study of cytotoxicity, oxidative stress and genotoxicity induced by four typical nanomaterials: The role of particle size, shape and composition. J Appl Toxicol. 2009; 29 (1): 69-78. DOl:10.1002/ jat.1385.

11. Nair S, Sasidharan A, Divya Rani W, Menon D, Nair S, Manzoor K et al. Role of size scale of $\mathrm{ZnO}$ nanoparticles and microparticles on toxicity toward bacteria and osteoblast cancer cells. J Mater Sci Mater Med. 2009; 20 (1): 235-41. DOI:10.1007/s10856-0083548-5.

12. Huang $X$, Teng $X$, Chen $D$, Tang F, He J. The effect of the shape of mesoporous silica nanoparticles on cellular uptake and cell function. Biomaterials. 2010; 31 (3):438-48. DOI:10.1016/j. biomaterials.2009.09.060.

13. Xiong $\mathrm{Y}$, Brunson $\mathrm{M}$, Huh J, Huang $\mathrm{A}$, Coster $\mathrm{A}$, Wendt $\mathrm{K}$ et al. The role of surface chemistry on the toxicity of $\mathrm{Ag}$ nanoparticles. Small. 2013; 9 (15): 2628-38. DOI:10.1002/smll.201202476.

14. Tarantola M, Pietuch A, Schneider D, Rother J, Sunnick E, Rosman $\mathrm{C}$ et al. Toxicity of gold-nanoparticles: Synergistic effects of shape and surface functionalization on micromotility of epithelial cells. Nanotoxicology. 2011; 5 (2): 254-68. DOl:10.3109 /17435390.2010.528847.

15. Tacar O, Sriamornsak P, Dass CR. Doxorubicin: An update on anticancer molecular action, toxicity and novel drug delivery

systems. J Pharm Pharmacol. 2013; 65 (2): 157-70. DOl:10.1111/ j.2042-7158.2012.01567.x.

16. Gautier J, Munnier E, Paillard A, Hervé K, Douziech-Eyrolles L, Soucé $M$ et al. A pharmaceutical study of doxorubicin-loaded PEGylated nanoparticles for magnetic drug targeting. Int J Pharm. 2012; 423 (1): 16-25. DOI:10.1016/j.ijpharm.2011.06.010.

17. Yu WW, Falkner JC, Yavuz CT, Colvin VL. Synthesis of monodisperse iron oxide nanocrystals by thermal decomposition of iron carboxylate salts. Chem Commun. 2004; (20): 2306-7. DOI:10.1039/b409601k.

18. Park J, An K, Hwang Y, Park JG, Noh HJ, Kim JY et al. Ultralarge-scale syntheses of monodisperse nanocrystals. Nat Mater. 2004; 3 (12): 891-5. DOI:10.1038/nmat1251.

19. Hai HT, Yang HT, Kura H, Hasegawa D, Ogata Y, Takahashi M et al. Size control and characterization of wustite (core)/spinel (shell) nanocubes obtained by decomposition of iron oleate complex. J Colloid Interface Sci. 2010; 346 (1): 37-42. DOI:10.1016/j. jcis.2010.02.025.

20. Simon T, Boca S, Biro D, Baldeck P, Astilean S. Gold-Pluronic core-shell nanoparticles: Synthesis, characterization and biological evaluation. J Nanoparticle Res. 2013; 15 (4): 1578. DOI:10.1007/ s11051-013-1578-5.

21. Gonzales M, Krishnan KM. Phase transfer of highly monodisperse iron oxide nanocrystals with Pluronic F127 for biomedical applications. J Magn Magn Mater. 2007; 311 (1): 59-62. DOl:10.1016/j.jmmm.2006.10.1150.

22. Zhou Z, Zhu X, Wu D, Chen Q, Huang D, Sun C et al. Anisotropic shaped iron oxide nanostructures: Controlled synthesis and proton relaxation shortening effects. Chem Mater. 2015; 27 (9): 3505-15. DOI:10.1021/acs.chemmater.5b00944.

23. Kolosnjaj-Tabi J, Di Corato R, Lartigue L, Marangon I, Guardia P, Silva AKA et al. Heat-Generating Iron Oxide Nanocubes: Subtle "Destructurators" of the Tumoral Microenvironment. ACS Nano. 2014; 8 (5): 4268-83. DOI:10.1021/nn405356r.

24. Guardia P, Di Corato R, Lartigue L, Wilhelm C, Espinosa A, Garcia-Hernandez M et al. Water Soluble Iron Oxide Nanocubes with High Values of Specific Absorption Rate for Cancer Cell Hyperthermia Treatment. ACS nano. 2012; 6 (4): 3080-91. DOI:10.1021/nn2048137.

25. Nemati Z, Alonso J, Martinez LM, Khurshid H, Garaio E, Garcia JA et al. Enhanced Magnetic Hyperthermia in Iron Oxide NanoOctopods: Size and Anisotropy Effects. J Phys Chem C. 2016; 120 (15): 8370-9. DOI:10.1021/acs.jpcc.6b01426.

26. Lee N, Kim H, Choi SH, Park M, Kim D, Kim H-C et al. Magnetosome-like ferrimagnetic iron oxide nanocubes for highly sensitive MRI of single cells and transplanted pancreatic islets. Proc Natl Acad Sci. 2011; 108 (7): 2662-7. DOl:10.1073/ pnas. 1016409108

27. Nizamov TR, Garanina AS, Grebennikov IS, Zhironkina OA Strelkova OS, Alieva IB et al. Effect of Iron Oxide Nanoparticle Shape on Doxorubicin Drug Delivery Toward LNCaP and PC-3 Cell Lines. BioNanoScience. 2018; 8 (1): 394-406. DOI:10.1007/ s12668-018-0502-y.

28. Kievit FM, Wang FY, Fang $\mathrm{C}$, Mok H, Wang K, Silber JR et al. Doxorubicin loaded iron oxide nanoparticles overcome multidrug resistance in cancer in vitro. J Control Release. 2011; 152 (1): 76-83. DOI:10.1016/j.jconrel.2011.01.024. 
1. Ling D, Hyeon T. Chemical design of biocompatible iron oxide nanoparticles for medical applications. Small. 2013; 9 (9-10): 1450-66. DOI:10.1002/smll.201202111.

2. Majewski P, Thierry B. Functionalized Magnetite Nanoparticles Synthesis, Properties, and Bio-Applications. Crit Rev Solid State Mater Sci. 2007; 32 (3-4): 203-15.DOI:10.1080/10408430701776680.

3. Xie J, Huang J, Li X, Sun S, Chen X. Iron oxide nanoparticle platform for biomedical applications. Curr Med Chem. 2009; 16 (10): 1278-94. DOI:10.2174/092986709787846604.

4. Oh JK, Park JM. Iron oxide-based superparamagnetic polymeric nanomaterials: Design, preparation, and biomedical application. Prog Polym Sci. 2011; 36 (1): 168-89. DOI:10.1016/j. progpolymsci.2010.08.005.

5. Laurent S, Forge D, Port M, Roch A, Robic C, Vander Elst L et al. Magnetic iron oxide nanoparticles: Synthesis, stabilization, vectorization, physicochemical characterizations and biological applications. Chem Rev. 2008; 108 (6): 2064-110. DOI:10.1021/ cr068445e.

6. Lin JJ, Chen JS, Huang SJ, Ko JH, Wang YM, Chen TL et al. Folic acid-Pluronic F127 magnetic nanoparticle clusters for combined targeting, diagnosis, and therapy applications. Biomaterials. 2009; 30 (28): 5114-24. DOl:10.1016/j.biomaterials.2009.06.004.

7. Andhariya N, Chudasama B, Mehta RV, Upadhyay RV. Biodegradable thermoresponsive polymeric magnetic nanoparticles: A new drug delivery platform for doxorubicin. J Nanoparticle Res. 2011; 13 (4): 1677-88. DOI:10.1007/s11051-010-9921-6.

8. Tavano L, Vivacqua M, Carito V, Muzzalupo R, Caroleo MC, Nicoletta F. Doxorubicin loaded magneto-niosomes for targeted drug delivery. Colloids Surfaces B Biointerfaces. 2013; (102): 803-7. DOl:10.1016/j.colsurfb.2012.09.019.

9. Jain TK, Foy SP, Erokwu B, Dimitrijevic S, Flask CA, Labhasetwar $\checkmark$. Magnetic resonance imaging of multifunctional pluronic stabilized iron-oxide nanoparticles in tumor-bearing mice. Biomaterials. 2009; 30 (35): 6748-56. DOI:10.1016/j.biomaterials.2009.08.042.

10. Yang $H$, Liu C, Yang D, Zhang $H$, Xi Z. Comparative study of cytotoxicity, oxidative stress and genotoxicity induced by four typical nanomaterials: The role of particle size, shape and composition. J Appl Toxicol. 2009; 29 (1): 69-78. DOI:10.1002/ jat.1385.

11. Nair S, Sasidharan A, Divya Rani W, Menon D, Nair S, Manzoor K et al. Role of size scale of $\mathrm{ZnO}$ nanoparticles and microparticles on toxicity toward bacteria and osteoblast cancer cells. J Mater Sci Mater Med. 2009; 20 (1): 235-41. DOI:10.1007/s10856-0083548-5.

12. Huang $X$, Teng $X$, Chen $D$, Tang $F$, He J. The effect of the shape of mesoporous silica nanoparticles on cellular uptake and cell function. Biomaterials. 2010; 31 (3):438-48. DOI:10.1016/j. biomaterials.2009.09.060.

13. Xiong $\mathrm{Y}$, Brunson $\mathrm{M}$, Huh J, Huang $\mathrm{A}$, Coster $\mathrm{A}$, Wendt $\mathrm{K}$ et al. The role of surface chemistry on the toxicity of $\mathrm{Ag}$ nanoparticles. Small. 2013; 9 (15): 2628-38. DOI:10.1002/smll.201202476.

14. Tarantola M, Pietuch A, Schneider D, Rother J, Sunnick E, Rosman C et al. Toxicity of gold-nanoparticles: Synergistic effects of shape and surface functionalization on micromotility of epithelial cells. Nanotoxicology. 2011; 5 (2): 254-68. DOI:10.3109 /17435390.2010.528847

15. Tacar O, Sriamornsak P, Dass CR. Doxorubicin: An update on anticancer molecular action, toxicity and novel drug delivery systems. J Pharm Pharmacol. 2013; 65 (2): 157-70. DOl:10.1111/ j.2042-7158.2012.01567.x.

16. Gautier J, Munnier E, Paillard A, Hervé K, Douziech-Eyrolles L, Soucé $\mathrm{M}$ et al. A pharmaceutical study of doxorubicin-loaded PEGylated nanoparticles for magnetic drug targeting. Int J Pharm. 2012; 423 (1): 16-25. DOl:10.1016/j.jpharm.2011.06.010.

17. Yu WW, Falkner JC, Yavuz CT, Colvin VL. Synthesis of monodisperse iron oxide nanocrystals by thermal decomposition of iron carboxylate salts. Chem Commun. 2004; (20): 2306-7. DOI:10.1039/b409601k

18. Park J, An K, Hwang Y, Park JG, Noh HJ, Kim JY et al. Ultralarge-scale syntheses of monodisperse nanocrystals. Nat Mater. 2004; 3 (12): 891-5. DOI:10.1038/nmat1251.

19. Hai HT, Yang HT, Kura H, Hasegawa D, Ogata Y, Takahashi M et al. Size control and characterization of wustite (core)/spinel (shell) nanocubes obtained by decomposition of iron oleate complex. J Colloid Interface Sci. 2010; 346 (1): 37-42. DOl:10.1016/j. jcis.2010.02.025.

20. Simon T, Boca S, Biro D, Baldeck P, Astilean S. Gold-Pluronic core-shell nanoparticles: Synthesis, characterization and biological evaluation. J Nanoparticle Res. 2013; 15 (4): 1578. DOI:10.1007/ s11051-013-1578-5

21. Gonzales M, Krishnan KM. Phase transfer of highly monodisperse iron oxide nanocrystals with Pluronic F127 for biomedical applications. J Magn Magn Mater. 2007; 311 (1): 59-62. DOl:10.1016/j.jmmm.2006.10.1150.

22. Zhou Z, Zhu X, Wu D, Chen Q, Huang D, Sun C et al. Anisotropic shaped iron oxide nanostructures: Controlled synthesis and proton relaxation shortening effects. Chem Mater. 2015; 27 (9): 3505-15. DOI:10.1021/acs.chemmater.5b00944.

23. Kolosnjaj-Tabi J, Di Corato R, Lartigue L, Marangon I, Guardia P, Silva AKA et al. Heat-Generating Iron Oxide Nanocubes: Subtle "Destructurators" of the Tumoral Microenvironment. ACS Nano. 2014; 8 (5): 4268-83. DOI:10.1021/nn405356r.

24. Guardia P, Di Corato R, Lartigue L, Wilhelm C, Espinosa A, Garcia-Hernandez M et al. Water Soluble Iron Oxide Nanocubes with High Values of Specific Absorption Rate for Cancer Cell Hyperthermia Treatment. ACS nano. 2012; 6 (4): 3080-91. DOI:10.1021/nn2048137.

25. Nemati Z, Alonso J, Martinez LM, Khurshid H, Garaio E, Garcia JA et al. Enhanced Magnetic Hyperthermia in Iron Oxide NanoOctopods: Size and Anisotropy Effects. J Phys Chem C. 2016; 120 (15): 8370-9. DOl:10.1021/acs.jpcc.6b01426.

26. Lee N, Kim H, Choi SH, Park M, Kim D, Kim H-C et al. Magnetosome-like ferrimagnetic iron oxide nanocubes for highly sensitive MRI of single cells and transplanted pancreatic islets. Proc Natl Acad Sci. 2011; 108 (7): 2662-7. DOl:10.1073/ pnas.1016409108.

27. Nizamov TR, Garanina AS, Grebennikov IS, Zhironkina OA, Strelkova OS, Alieva IB et al. Effect of Iron Oxide Nanoparticle Shape on Doxorubicin Drug Delivery Toward LNCaP and PC-3 Cell Lines. BioNanoScience. 2018; 8 (1): 394-406. DOI:10.1007/ s12668-018-0502-y.

28. Kievit FM, Wang FY, Fang C, Mok H, Wang K, Silber JR et al. Doxorubicin loaded iron oxide nanoparticles overcome multidrug resistance in cancer in vitro. J Control Release. 2011; 152 (1): 76-83. DOl:10.1016/j.jconrel.2011.01.024. 